\title{
From fear to anxiety in Shakespeare's Macbeth
}

\section{Christine Sukic}

\section{OpenEdition \\ Journals}

\section{Édition électronique}

URL : https://journals.openedition.org/shakespeare/4141

DOI : 10.4000/shakespeare.4141

ISSN : 2271-6424

\section{Éditeur}

Société Française Shakespeare

\section{Référence électronique}

Christine Sukic, "From fear to anxiety in Shakespeare's Macbeth", Actes des congrès de la Société française Shakespeare [En ligne], 36 | 2018, mis en ligne le 07 octobre 2019, consulté le 25 août 2021. URL : http://journals.openedition.org/shakespeare/4141 ; DOI : https://doi.org/10.4000/shakespeare. 4141

Ce document a été généré automatiquement le 25 août 2021.

(c) SFS 


\title{
From fear to anxiety in Shakespeare's Macbeth
}

\author{
Christine Sukic
}

1 In the early modern period, fear was either a necessary passion, as when Christians are said to live in the "fear of God" , or an emotion that had to be suppressed or at least mitigated, when it concerned the "fear of death". There are numerous books of ars moriendi that claim, in their titles, that they intend to "take away the feare of death" will "comfort" Christians against that fear ${ }^{3}$. In a Christian context, fear was thus seen as a sort of natural passion, which was acceptable as long as it was "holy fear", as Emilia calls it in Two Noble Kinsmen (5.1.149), but that had to be alleviated in order for Christians to "die well", with as little fear as possible. In Measure for Measure, Claudio seems to have learned to "encounter darkness as a bride / And hug it in [his] arms" (3.1.83-4) until Isabella's visit reminds him that "Death is a fearful thing" (3.1.115).

2 At a time when moral philosophers were discussing the status of the passions and their significance, the passion of fear was most commonly envisaged in a moderate waymainly under the influence of Aristotle. Jacques Hurault, who was Henri III of France's councillor, recommended, like many of his contemporaries, control over the passions in Les Trois livres des offices d'Estat (1586), his work about the education of princes that was translated into English by Arthur Golding and published in 1595 under the title Politicke, Moral, and Martial Discourses:

Let us for example take Hardines, which is a meane betweene Fearfulnesse and Over-boldnesse, of which two this latter is the excesse of boldnesse, in offering a mans selfe to danger, and the other is the default or want of boldnesse in the same case, when Boldnesse is requisit or expedient. ${ }^{4}$

3 Fearfulness is here defined as excess, while its opposite is the absence of fear ("Overboldnesse"). For Hurault, the ideal position towards those passions is "hardiness", which he sees as a middle ground between two excesses. He insists on the importance of the absence of fear, a cardinal virtue that can be called "Fortitude, Prowes, or Valiantnesse" and that he opposes to "Fearfulnesse or Cowardlinesse": "This vertue is more generallie followed of princes", Hurault adds. ${ }^{5}$ In other words, fear is defined in a negative way, as its absence is a princely and heroic virtue. Hurault thus introduces a 
social dimension in the definition of fear by attributing its opposite, a cardinal virtue, to princes and great men ("as we have seene in Alexander, Pirrhus, Hanniball, Pompey, Iulius Caesar, Themistocles, Alcibiades, and manie others"). ${ }^{6}$ The absence of fear could therefore be seen as a definition of heroism, as Hurault's list of great men suggests here. Unsurprisingly, he also associates the absence of fear to the value of honour:

Aristotle saith, It is the dutie of Prowesse to be utterlie undismaied with the feare of death, to be constant in suffering adversitie, to be void of dread of danger, to chuse to die with honour, than to live with dishonour, or to be conquered in battell. At a word, it is the dutie of prowesse, to be unafraid of any dangers, which reason sheweth that we ought not to feare. ${ }^{7}$

The social dimension of fear and courage is confirmed by military memoirs such as the Discourses of the Huguenot captain François La Noue, who writes-in the 1588 English translation-that "There are other reasons, besides the equitie of a cause and urgent necessitie, that stirre up men to fight couragiously: As the presence of noble persons which detest cowardlinesse and exalt prowess". ${ }^{8}$

Shakespeare partakes of the same social framing when it comes to fear and courage: when war is at stake, courage is exalted and generates greatness while cowardice is scorned and defines base men. Henry V excites his men to action with "greater courage" in a situation of "great danger" (4.1.1), while cowardice is associated with the treachery of Cambridge, Grey and Scroop-their blood is "cowarded" (2.2.72)-or with the baseness of Pistol. In 1Henry IV, Shakespeare also opposes fear and courage by staging the death of the fearless hero Hotspur while having Falstaff stage his own counterfeit heroic gest and dismiss "honour" as an empty value (5.1.134). In Macbeth, Shakespeare envisages another kind of opposition between courage and fear, since it concerns the same character, a brave warrior that becomes a fearful and tormented tragic hero.

When Macbeth comes back from the war, after his encounter with the Weird Sisters, he and Banquo are met by Ross who reports to him the admiration of King Duncan for his brave action at war: "He finds thee in the stout Norweyan ranks, / Nothing afeard of what thyself didst make, / Strange images of death" (1.3.95-97). This passage confirms what we witness in 1.2, when at the King's camp, messengers come in, full of stories of war containing what Robin Headlam Wells calls "the obscene detail of epic convention", 9 evoking narratives of men with "brandish'd steel", smoking with "bloody execution", where wounds do not provoke fear but "smack of honour" (1.2.17-18 and 45). Macbeth is part of this martial world of epic heroism where great men are brave and are not afraid of "strange images of death". And yet, as soon as he learns he has been made Thane of Cawdor, he is immediately taken by the most terrible fear:

If good, why do I yield to that suggestion

Whose horrid image doth unfix my hair,

And make my seated heart knock at my ribs,

Against the use of nature? Present fears

Are less than horrible imaginings (1.3.134-8).

7 While he is not affected by anything that is under his eyes ("Present fears"), what he discovers inside himself he finds to be worthy of terror, as he confirms it himself a few lines further down in order to explain to his companions why he was so lost in his thoughts: "my dull brain was wrought / With things forgotten" (150-1). This fear of the self is further explained by Macbeth in the next scene, when he refuses to see his "black and deep desires", that which "the eye fears" (1.4.51-3). 
This opposition takes the form of a passage from a world in which fear does not seem to exist, where no spectacle is able to frighten a heroic character, be it a "strange image of death", to another one in which something that does not exist materially is an object of fear for a former martial hero. More than just a social reconfiguration, this passage illustrates an epistemological crisis according to which fear is no longer a social criterion, that which defines a social class against another, or a superior class of heroes against the rest of the world, but a passion that affects all humankind, therefore defining humanity. As such, it is integrated into Shakespearean drama as a source of fiction: fear creates stories.

The beginning of Macbeth corresponds to a common discourse-literary or not-in the early modern period, a topos that states that fear is the opposite of bravery, and that noblemen are characterised by courage. The great French historian of fear, Jean Delumeau, in his seminal book about fear in the western world, (La Peur en Occident, first published in 1978), pointed to the early modern taste for that literary discourse glorifying temerity and courage, virtues that were associated with the upper classes, seen as fearless in the conduct of war, while the masses were generally defined as being without courage. He cites a classical source ${ }^{10}$ that, according to him, already established that difference between high and low birth, when Virgil, in the $4^{\text {th }}$ book of the Aeneid, dissociated fear from nobility and had Queen Dido exclaim about Aeneas: "Who is this stranger guest who has entered our home? How noble his mien! How brave in heart and feats of arms! I believe it well-nor is my confidence vain-that he is sprung from gods. It is fear that proves souls base-born" ${ }^{11}$ Fear is here relegated to the lower, non-heroic categories of humans. There are some emblematic models of those fearless classes such as Jean Ier de Bourgogne, John the Fear-Less at the turn of the $14^{\text {th }}$ and $15^{\text {th }}$ centuries, or Bayard, the knight "without fear or beyond reproach", who lived about a century later. Closer to Shakespeare, after the assassination of the French king Henry IV, the Huguenot writer and translator Jean Loiseau de Touval called Henry "That Peerless, Fearless Hercules", ${ }^{12}$ and imagined, on the other hand, his enemies tremble with fear at the evocation of his name: "The Poles did tremble at my conquest's sound, / Th'Antipodes did feare my victories". ${ }^{13}$

10 This vision of fear as a social marker seems to have been a commonplace at the time. In the descriptions of fear found in moral philosophy, and in the moral treatises about the passions especially, the theatre of war is the place where this social distinction can be best explained, that is to say, a situation where the body is involved and subject to danger. It is obvious in Montaigne, who devoted a short essay to fear, entitled "Of feare" in Florio's translation. Montaigne describes the physical and mental effects of this passion, and from the very beginning of the essay, envisions it as a social marker which affects the "Vulgar sort"14 more than members of the nobility, soldiers more than commanders or officers, since the subject of fear immediately leads Montaigne to that of war:

But even amongst Souldiers, with whom it ought to have no credit at all, how often hath she changed a flocke of sheep into a troupe of armed men? Bushes and shrubbes into men-at-armes and Lanciers? our friends into our enemies? and a red crosse into a white? ${ }^{15}$

11 Pierre Charron goes even further, in his Livre de la sagesse, a book shaped by the ideas of Montaigne as well as by neo-Stoicism, which was published in English in 1608 as of wisdome three bookes written in French (translated by Samson Lennard) ${ }^{16}$. Charron strongly condemns fear in the chapter devoted to that passion, except when it concerns 
the fear of God. Apart from this case that seems to be set outside the rest of his reflection, Charron defines fear as "a deceitfull and malicious passion" that cultivates a "doubtfull darkenesse" ${ }^{17}$ holding us in a "darke place, as theeues do by night" Charron is also interesting in that he constantly opposes wisdom (the subject of his book) to the opinion of the "vulgar sort". He devotes one chapter to those people whom he describes as either fearful or too audacious ("People or vulgar sort", first book, chap. 52). They are "either out of hope too much trusting, or too much distrusting out of feare. They will make you afeard, if you feare not them: when they are frighted, you chocke them under the chin, and you leape with both feet upon their bellies. They are audacious and proud, if a man shew not the cudgell" ${ }^{19}$.

This mistrust of the "vulgar sort", and their association with cowardice is also exemplified on the early modern stage. One of the most striking examples of this is to be found in Francis Beaumont's The Knight of the Burning Pestle, a play endowed, as its publisher states it, with a "privy mark of irony" (Epistle, 1. 5). ${ }^{20}$ In this play that was presumably first performed at the Blackfriars by the Children of the Revels in 1607 or 1608 , Rafe, the grocer's apprentice, becomes a knight-errant in the play within the play, or, as he himself says, "grocer-errant" (1.1.259). At the end of his adventures, before the epilogue, Rafe exhorts his troops as a brave knight would do, asking his men not to be afraid of war-action:

Gentlemen, countrymen, friends, and my fellow-soldiers, I have brought you this day from the shops of security and the counters of content, to measure out in these furious fields honour by the ell, and prowess by the pound. Let it not, oh, let it not, I say, be told hereafter the noble issue of this city fainted, but bear yourselves in this fair action like men, valiant men, and freemen. Fear not the face of the enemy, nor the noise of the guns, for believe me, brethren, the rude rumbling of a brewer's cat is far more terrible, of which you have a daily experience [...]. (5.1.138-147)

13 As we see in the vocabulary used by Rafe referring to his trade (shops, counters, measure out, the ell, etc.), the whole exhortation-and the character himself-has to be read ironically. The same could be said about the end of the play, when he reappears after his death as a ghost evoking his former constipation. Rafe is supposed to be an object of ridicule, and if he is, it is mainly because the part he has to play on stage-a fearless knight-errant-does not correspond to his social class: he should be afraid, and he is brave. The play thus uses the clichés of the bravery of the aristocracy in an ironic way, applying them to a character that is out of place. This inversion is the basis of this comedy, in which the absence of fear induces ridiculous heroics.

We also find examples of this topos in a play where, as we have already seen it, war plays a great part, Henry $V$, in which the absence of fear characterises both sides, the English, but also the French, who represent an obsolete type of heroism. Henry uses another cliché, that of fear as an instrument of war, almost a weapon. In 3.1, he asks his men to "lend the eye a terrible aspect [...], let the brow o'erwhelm it / As fearfully as doth a galled rock..." (9-12). Whitney's emblem of "Furies \& rabies"-an emblem devoted to anger, the passion that incites men to fight-depicts Agamemnon's shield, full of terrible figures meant to provoke fear (griffins, lions, dragons, and, like in Henry $V$, tigers) and bearing the following verse: "Man's terror this, to fear them that behold: / Which shield is borne, by AGAMEMNON bold" ${ }^{21}$. Those shields decorated with objects of fear such as Medusa's heads-imitating Athena's shield-were quite common in the early modern period, usually as parade shields ${ }^{22}$. It is interesting that anger and fear should be associated in this emblem, as those two passions are seen as positive 
instruments of war for heroic men, the first one to give courage in battle, and the second to frighten one's enemies. In the treatises of the passions, fear is either condemned (like anger, really) but can also be seen in a positive way. Nicolas Coeffeteau, for instance, in the Table of Humane Passions (1620), whom I am quoting here in Grimeston's translation (1621), says there is also "a kinde of moderate feare, which striking reason but gentlely, makes us advised (to the which the Stoickes give the name of circumspection) to provide with judgement for that which concernes us: for that it makes us carefull and atentive to looke to our affaires, and to give order for that which is necessary to shelter us from stormes". ${ }^{23}$ Following in that Aristotle, Coeffeteau points to a more positive use of the passion, which can have a positive effect, a moral one that makes us "advised" and gives us "judgement". Thomas Wright, in The Passions of the minde, goes further because he uses the topos of fear as an instrument of war, when he tells his readers how fear can be "moved". Instead of viewing fear as the passion that prevents heroic action, he sees it as one that can be the trigger to moral action and therefore heroic action. He cites the example of war against "the Turk". According to him, by stating all the dangers and the threats represented by the Turkish enemy, one might be able to move somebody to martial action. It is, therefore, by the fear of the Other that Wright purports to turn fear into a positive passion:

The children who are warlike in their infancy perforce shall be taken from their parents and sent into a far country from them, and there trained up in martial prowess and Turcism, and forget both father and mother, country and kindred, and neither yield comfort ever to progenitors nor receive any comfort from them. Many more such tyrannical vexations and barbarous cruelties I could recount, but he that will not be moved with these I hold him neither a wise moral man nor any way touched with one spark of Christian zeal ${ }^{24}$.

Of course, it is another type of war that is fought in Henry $V$, but fear is also used as a weapon, such as when the French king exhorts the Dauphin and the great nobles to use their "spirit of honour" (3.6.38). The Constable of France hopes that fear will help them in this enterprise: "I am sure when he shall see our army / He'll drop his heart into the sink of fear, / And for achievement offer us his ransom" (58-60). Like Hotspur in 1Henry $I V$, the Dauphin is eager to fight and does not seem to be affected by fear. He is a "gallant prince", as Orléans calls him (III. 7. 96-7). Most of the martial action is characterised by bravery, except for the characters of Bardolph, Nym, and Pistol, who have to be driven forward by Fluellen, and are called "these three swashers" by the boy (3.2.28-9). Pistol is definitely dismissed in act V.1 when Gower calls him "a counterfeit cowardly knave" (72) and he himself says how he will invent stories of the "Gallia wars" about the "cudgell'd scars" (92-3) he just got from Fluellen.

In fact, Henry $V$ only mentions fear as a deterrent in war, or as a base passion affecting villains who are eliminated from the stage and the theatre of war anyway. But the presence of those cowards does affect the perception we get of this great epic narrative. As we have already seen in with the counter-example of Falstaff in 1 Henry IV, the absence of fear is part of the culture of honour. However, there seems to be a reconfiguration of the idea of fear as a social marker in the dramatic literature of the period.

17 It is especially obvious in scenes that are characterised not by fear, but on the contrary, by an absence of fear, moments in Shakespearean drama when there is danger, or a situation that suggests a threat. One of the characters-who is not aristocratic and more often than not a secondary character-overcomes their fear in order to achieve a 
surprising act of courage. When, in King Lear, Gloucester is being tortured on stage by Regan and Cornwall, the first Servant, maybe emboldened by Gloucester's courageous attitude in spite of his old age, and repulsed by his daughter and son-in-law's cruelty, takes the defence of the old man and courageously stands up to Cornwall: "Hold your hand, my Lord. / I have serv'd you ever since I was a child, / But better service have I never done you / Than now to bid you hold" (3. 7. 70-73). Further down, as the same servant takes up his sword and challenges the nobleman, Cornwall is stunned by his audacity: "My villain!" (76), he exclaims. Regan cannot stand the social infringement this represents: "Give me thy sword. A peasant stand up thus!" (78) and kills him, presumably from behind. The social transgression represented by this character is striking here: he is in charge of the heroic action on stage at that moment in the play, while Gloucester, the old man, is unable to react, being in a passive position, tortured by Regan and Cornwall, whose cowardice is marked in the text by several visual signs (the fact that the servant is killed from behind, while he is having a go at Cornwall with his sword; that Gloucester is defenceless and tortured while being tied to a chair; that he is old; that the confrontation is uneven with the old man being attacked by a rather young couple).

There are, in fact, several scenes of this kind in Shakespearean drama, scenes that are similar to this one not so much in terms of plot or situation, but rather because of this social pattern indicating a discrepancy, where a character of a lower social class is suddenly put to the forefront thanks to an act of bravery, while the nobleman or noblemen are stigmatised for their fearful lack of courage. Another relevant example can be found in Antony and Cleopatra, when Antony thinks that Cleopatra has killed herself and wants to die but is unable to do so, pointing to his own "baseness" and lacking, he says, "The courage of a woman" (4.14.60). He is afraid of killing himself, he who has with his sword, "Quartered the world, and o'er green Neptune's back / With ships made cities" (57-59), and so he asks Eros to do it for him, to be brave instead of his own heroic self. And there again, Shakespeare stresses the contradiction between Antony's status as a great Roman general and his baseness, his lack of courage, and, on the other hand, that between Eros's social baseness-he is a slave that has been enfranchised by Antony-and his capacity to be heroic at this point in the play, to be, as Antony remarks once Eros has killed himself instead of killing Antony, "Thrice nobler than myself!" (95), that is to say to have gained a sort of nobility that has nothing to do with social class but with the lack of fear, an attitude that befits a hero.

Social inversion can go even further, as in the anonymous A Larum for London, Or the Siedge of Antwerpe (1602) 25 . The play is about the three-day sack of Antwerp (or "Spanish Fury") by unpaid and mutinous Spanish troops in 1576 and takes the form of a "warning" to London (the alarum of the title). As the epilogue states it, this "may be a meane all Cittyes to affright" (Epilogue, 1.1677). So the play is supposed to provoke a valuable reaction of fear, but in its plot, the city of Antwerp is characterised by fear and cowardice, on the part of the citizens (the Burghers) and the governor of the city, who are afraid of offending the Spaniards if they accept the reinforcement from the Prince of Orange, and who are unable to react. Their cowardice is also marked by a gender inversion, when the wife of one of the burghers points to his lack of courage: "For shame, / Be not so fearefull [...]/ Have yee not Soldiers to withstand their force?" (l. 507-511). In the meantime, the only brave character is the poor soldier who is the hero of the play, Vaughan, or Stump, called so because he has lost one of his legs. After his 
death, his body is treated like that of a hero and he is said to have a "Heroycke spirit [...]" (l. 1649).

This social remapping of fear is in keeping with the more general reconfiguration of heroism in the early modern period: it signals changes in the perception of the aristocracy and the fearless conduct of war and, in the literary field, a questioning of the values conveyed by the classic epic narrative. To come back to Macbeth, if his fear is absent on the battlefield, after the murder of Duncan it never leaves him: "I am afraid to think what I have done" (2.2.50), he utters. Fear even materialises on stage, when Banquo comes to haunt him. Lady Macbeth rebukes him for that passion:

This is the very painting of your fear;

This is the air-drawn dagger which you said

Led you to Duncan. O, these flaws and starts,

Impostors to true fear, would well become

A woman's story at a winter's fire

Authorised by her grandam (3.4.70).

21 Lady Macbeth, in character, is accusing him of being a coward, and gendering his cowardice, as she has done almost from the beginning of her presence on stage. The words she uses in this passage are particularly interesting, when she refers to "painting", and opposes "true fear", to these "impostors". In fact, she is referring to Macbeth's fears as fiction, as imagination. She is, indirectly, suggesting that there is efficient imagination at work-able, let us remember, to place a character on stage, Banquo, a character that the audience can see. There is, in this passage, a contradictory poetic art, a poetics of fear in reverse that tries to deny what we see on stage: that fear creates fiction.

This is, by the way, suggested by many authors of the period, such as Montaigne who says that this "strong Passion" materialises the objects of fear. The "vulgar sort", he says, imagine those objects in various guises, be they "their Great-Grandsires, risen out of their Graves in their Shrowds", or "Hob-Goblins, Spectres and Chimaera's." ${ }^{26}$ Montaigne gives the case of "Souldiers", "a sort of men", he says, "over whom, of all others, it ought to have the least Power", but who are also occasionally given to this passion, and whose fear also materialises their phobias: "how often has it converted Flocks of Sheep into armed Squadrons, Reeds and Bull-rushes into Pikes and Launces, Friends into Enemies, and the French White into the Red Crosses of Spain!" ${ }^{27}$ Charron also stresses the materialisation of fear that places before the eyes of the fearful subject all sorts of images. We could say that it is a very creative passion that translates to fiction, in a way: "it tormenteth us with masks and shewes of evils, as men feare children with bug-beares." 28

Some authors-such as Coeffeteau-remark on the difficulty to define this passion because, as he says, even though it can have tremendous effects, it remains unseen, and difficult to envision: "although shee seeme not to bee so active as the rest, and remaines as it were covered and hidden, yet she doth cause strange accidents in the life of man; for that shee hath sometimes ruined powerfull Armies, brought Kingdomes and States into dangers, and overthrowne the fortunes of private persons." ${ }^{29}$ So there is a kind of duality about this mysterious passion that is difficult to perceive, but that also has an almost material effect on imagination. Coeffeteau concludes his chapter about fear by pointing out that it "doth wholly trouble the imagination of man." ${ }^{30}$ So, like the other passions, it has an effect on the human body-that is the reason why the passions 
were also called the "motions" of the soul-but more than the other passions, it has a strong power of imagination.

At the end of the play, Macbeth states that he has "almost forgot the taste of fears" (5.5.9), the word "taste" suggesting a materialisation of the objects of fear, things one can taste and things one "sups" on since Macbeth also says he has "supped full with horrors". So this is a contradictory statement that, first of all, triggers Macbeth's speech ("She should have died hereafter", 5.2.16), a great moment of lucidity at the news of Lady Macbeth's death, and a form of tragic knowledge about the insignificance of man. The references to the materialisation of fear are counterbalanced by the images of insubstantiality contained in Macbeth's speech. This passage is situated, by the way, in between two moments when his tragedy takes on an ironic turn as reality denies his absence of fear: Macbeth first strongly asserts that he "will not be afraid of death and bane, / Till Birnam Forest comes to Dunsinane" (5.3.58-60); however, at 5.5, he is toldprobably fearfully-by the messenger: "I looked toward Birnam and anon methought / The wood began to move" (32-3). I suggest that, at that moment in the play, when the materiality of fear turns to immaterial images and impalpable elements, Macbeth is, indeed, not so much affected by fear as he is by anxiety, in a sense that is defined by the OED as "Worry about the future or about something with an uncertain outcome [...]; a troubled state of mind arising from such worry or concern" (first entry). Contrary to fear, anxiety concerns the mind more than it concerns imagination. Thomas Cooper's dictionary translates the Latin scrupulositas as "Anxietie: curiousnesse of conscience: scrupulositie: spiced conscience" ${ }^{31}$. The word "anxiety", as in this example, is often coupled with "scrupulosity". Interestingly, even though the OED gives 1475 as the first known occurrence of the word, it is quite rare to find it before 1600, and it is used a lot more after 1650. The association with "scrupulosity" shows that it also has a moral dimension, which is another indication of its intellectual rather than passionate quality.

In Macbeth, the hero undergoes a change, from an absence of fear that characterises an obsolete kind of heroism, to anxiety expressed about a world that is unknowable, illusory, and impalpable. This shift from one state to another is visually represented by a contradiction between the material and the immaterial, between the ghost, or the advancing wood, and the "walking shadow". This is characteristic of the Shakespearean tragic self. In Hamlet, the hero's incapacity to act is also situated between an archaic world that appears on stage, that of the ghost first perceived as a "goblin damned" or a "questionable shape", words that are reminiscent of the descriptions of the effects of fear (in Montaigne, for instance), and this "conscience" that Hamlet mentions, that prevents him from acting. "Am I a coward?", Hamlet asks in 2.2, (in the "O what a rogue and peasant slave am I" monologue) and at 3.1, he answers that "conscience makes cowards of us all". This "cowardice" is not socially marked since it affects "us all". Conquering fear on the stage of Hamlet does not mean being able to act but on the contrary leaving the archaic world of action behind, becoming a coward, like "us all". 


\section{NOTES}

1. Amongst numerous examples: Henry Smith, The preachers proclamacion Discoursing the vanity of all earthly things, and prooving that there is no contentation to a Christian minde, but onely in the feare of God, London, 1591.

2. Jean de l'Espine, A treatise tending to take away the feare of death, and make the faithfull man desire the same..., London, 1619.

3. Stephen Jerome, Seaven helps to Heaven Shewing [...] Comforts for Christians against distresses in life, and feare of death, London, 1614.

4. Jacques Hurault, Politicke, Moral, and Martial Discourses. Written in French by M. Iaques Hurault, lord of Vieul and of Marais, and one of the French kings privie Councell. Dedicated by the Author to the French-kings Maiestie: And translated into English by Arthur Golding, London, Printed by Adam Islip, 1595, p. 59.

5. Ibid., p. 275.

6. Ibid.

7. Ibid., p. 275-276.

8. François La Noue, The politicke and militarie discourses of the Lord de La Nouue Whereunto are adioyned certaine observations of the same author, of things happened during the three late civill warres of France. With a true declaration of manie particulars touching the same. All faithfully translated out of the French by E.A., At London, Printed for T. C. and E. A. by Thomas Orwin, 1588, p. 275.

9. Robin Headlam Wells, Shakespeare on Masculinity, Cambridge University Press, 2004, p. 119.

10. Jean Delumeau, La Peur en Occident (XVI ${ }^{\mathrm{e}}$-XVIII ${ }^{\mathrm{e}}$ siècles), Paris, Librairie Arthème Fayard, 1978, p. 15.

11. Virgil, Aeneid, IV.10-12, in Eclogues. Georgics. Aeneid I-VI, trans. H. Rushton Fairclough, revised by G. P. Goold, The Loeb Classical Library, Cambridge, Mass, London, England, Harvard University Press, 1999, p. 423.

12. Jean Loiseau de Tourval, Three precious teares of blood, flowing from the wounded harts of three great French ladies In memory, of the vertues, complaint of the losse, and execration of the murther, of that thrice-worthy monarch, Henry the Great. Now shed againe in English...,Printed at Britaine Burse for John Budge, and are there to be sold at his shop, 1611, p. 15.

13. Ibid., p. 7.

14. Montaigne, Essays..., transl. John Florio, 1613 edition, Book 1, chapter 17, "Of feare", p. 28.

15. Ibid.

16. Pierre Charron, Of wisdome three bookes written in French by Peter Charro[n] Doctr of Lawe in Paris, translated by Samson Lennard, 1608.

17. Ibid., p. 99.

18. Ibid., p. 100.

19. Ibid., p. 201.

20. Francis Beaumont, The Knight of the Burning Pestle, ed. Michael Hattaway, New Mermaids, London, Methuen Drama, 2002.

21. Geffrey Whitney, A choice of emblemes, and other devises, For the moste parte gathered out of sundrie writers, Englished and Moralized. And divers newly devised, Leyden, In the house of Christopher Plantyn, by Francis Raphelengius, 1586, p. 45, in Whitney's "Choice of Emblemes". A fac-simile reprint, ed. Henry Green, London, Lovell Reeve \& Co., Chester, Minshull \& Hughes, Nantwich, E. H. Griffiths, 1866.

22. There is a beautiful example of a parade shield of embossed steel with Medusa's head in the centre, at the Victoria and Albert Museum, dated 1552 and made in Augsburg by Jörg Sigman, a 
famous German goldsmith (Museum number 3660-1855). URL: https://collections.vam.ac.uk/ item/097494/parade-shield-sigman-jorg/, accessed 25 August 2017.

23. Nicolas Coeffeteau, A Table of humane passions. With their Causes and Effects. Written by ye Reverend Father in God F. N. Coeffeteau, Bishop of Dardania, Councellor to ye French King in his Councels of Estate, Suffragane and Administrator gelnerall of ye Bishopricke of Metz. Translated into English by Edw: Grimeston Sergiant at Armes, London, Printed by Nicholas Okes, 1621, p. 572.

24. Thomas Wright, The Passions of the Mind in General, ed. William Webster Newbold, The Renaissance Imagination, vol. 15, New York and London, Garland Publishing, 1986, p. 286.

25. I am using the Malone Society Reprint edition of 1913.

26. Montaigne, Essays, op. cit., p. 83.

27. Ibid.

28. Pierre Charron, of wisdome three bookes, op. cit., p. 100.

29. Nicolas Coeffeteau, The Table of Humane Passions, op. cit., p. 429.

30. Ibid., p. 472.

31. Thomas Cooper, Thesaurus linguae Romanae \& Britannicae..., Impressum Londini, 1578.

\section{RÉSUMÉS}

Jean Delumeau, dans sa célèbre histoire de la peur (La Peur en Occident, 1978), montre les aspects sociaux de la peur à l'époque moderne: un noble est par définition sans peur, alors que «le vulgaire » (Montaigne, « De la peur ») est considéré comme excessivement peureux et couard. La peur, passion "servile et honteuse " (Coeffeteau, Tableau des passions humaines, 1620) dépend donc de son contraire traditionnel, le courage, et se place dans ce cadre dialectique. On trouve cette opposition sociale dans la plupart des discours sur la peur de la première modernité : la peur est donc vue comme caractéristique des classes populaires, alors que le courage est associé à l'individualité aristocratique. A partir de ce constat, cet article étudie la façon dont le théâtre shakespearien sape cette opposition sociale en mettant en scène des actes de courage accomplis par des humbles, tout en faisant de la peur le fondement du sujet moderne, la peur n'étant plus un défaut mais le fondement d'une définition de l'humain. Enfin, Shakespeare fait de la peur le fondement d'une poétique.

Jean Delumeau, in his seminal history of fear (Fear in the West, first published in 1978) points to the social configurations of fear in early modern societies: a nobleman was by definition fearless, while people of the "Vulgar sort" (Montaigne, "Of fear") were taxed with being excessively fearful and cowardly. Fear, "a servile and base passion" (Coeffeteau, A Table of Human Passions, 1620) was thus determined by its traditional reverse, bravery, and placed within that dialectic frame. That social opposition structures most early modern discourses about fear and informs a vision of fear as being characteristic of the popular masses, while bravery is associated with aristocratic individuality, desire for fame and heroism. Bearing in mind this dominant discourse, I would like to look at the ways in which Shakespearean drama undermines this social framework by staging humble representations of acts of bravery, while at the same time using fear as a fundamental basis for the modern subject, no longer a defect but as a defining trait of humankind. Fear becomes a source of fiction on the Shakespearean stage. Key words: 
INDEX

Keywords : Anxiety, aristocracy, bravery, fear, heroism, passions, poetic art, Shakespeare

Mots-clés : Peur, anxiété, courage, passions, aristocratie, héroïsme, art poétique, Shakespeare William

\section{AUTEUR}

\section{CHRISTINE SUKIC}

Université de Reims Champagne-Ardenne 